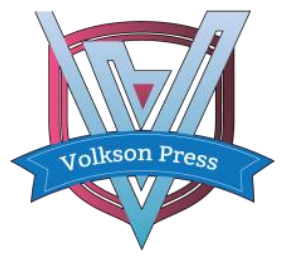

Economics, Finance and Statistics (EFS)

DOI : http://doi.org/10.26480/icefs.01.2018.13.16

\title{
THE IMPACT OF CAPITAL MARKET MISPRICING ON THE FINANCING CHOICE FOR CORPORATE WITH DIFFERENT FINANCIAL CONSTRAINTS
}

\author{
Ling chen, Bao Wenbin \\ Department of Nanjing University of Science and Technology, Xuanwuqv Xiaolingwei 200, Nanjing, China \\ Institute of Nanjing University of Science and Technology, Xuanwuqv Xiaolingwei 200, Nanjing, China \\ *Corresponding Author's E-mail: lsbccj@sina.com
}

This is an open access article distributed under the Creative Commons Attribution License, which permits unrestricted use, distribution, and reproduction in any medium, provided the original work is properly cited.

\section{ARTICLE DETAILS}

\section{Article History:}

Received 12 March 2018 Accepted 12 April 2018 Available online 15 May 2018

\section{ABSTRACT}

China's capital market has been non-effective for a long time, and the prices of securities have been subject to frequent abnormal changes. Capital markets is an important financing place for the real economy. The mispricing of the capital market will inevitably have an impact on the listed companies' equity and debt financing. This paper takes China's listed companies as the research object, using the annual financial data of listed companies in China A stock market from 2006 to 2015, using discretionary accrued profits and dividend payout as a measure of market mispricing and corporate financial-constraints respectively to explore the impact of the capital market mispricing on the financing choice for companies with different financial-constraints. The results show that mispricing has a significant positive effect on companies' equity financing and debt financing regardless of financial constraints. Specifically, we find that the positive effect of mispricing on equity financing of high financial-constraints companies is lower than that of low financial-constraints companies. However, for debt financing, the result is opposite.

\section{KEYWORDS}

Mispricing, capital market, equity financing, stock market, debt financing.

\section{INTRODUCTION}

As an emerging capital market, there are many deficiencies in China's capital market. The ineffectiveness of the market and the irrational fluctuations in the prices of securities will not be changed in the long run. The volatility of securities prices will significantly affect the size of the company's capital costs and risks, thus affecting the follow-up refinancing and business operations.

There are two prominent characteristics of the financing of listed companies in China. First, listed companies prefer equity financing. Equity financing accounted for the largest share of total corporate finance. As a result, corporate finance is more susceptible to the mispricing of capital markets. Second, the domestic listed companies generally face severe financial constraints. External financing costs are higher. Therefore, the listed companies always make financing decisions after taking both the favorable timing of financing caused by the mispricing in the capital market and the financial constraints into consideration.

Research showed that the rational corporate manager will utilize the favorable market timing for financing to reduce capital costs and enhance corporate value [1]. Empirical studies confirm that IPO issuance of listed companies is always accompanied by an overestimation of share prices, while stock repurchases often appear with the undervaluation of share prices [2,3]. A group of researchers point out that the major shareholders of an enterprise can utilize information asymmetry, carrying out earnings management to enhance the stock value and reduce the financing cost [4]. Others conduct a questionnaire survey of listed company's CFOs and find that managers would choose the timing of financing according to the market performance of the company's stock [5,6]. Domestic research also points out that there are market timing in the financing decisions of listed companies [7-9]. Further, considering the status of government intervention and policy control in domestic capital markets, Some scholars point out that stock issuance of domestic enterprises not only bases on their own market-timing behavior but also bases on government regulatory policies, the latter being more significant $[10,11]$.

With the linkage between the stock market and the bond market, fluctuations in stock prices often lead to fluctuations in bond prices, thereby affecting the cost of corporate debt financing. Empirical studies confirm that stock prices have a significantly effect on the equity and debt financing of listed companies point out that the overestimation of the stock price will reduce the debt cost [13-14]. Contradicting the above scholars, other scholar point out that the market timing only exists in the equity financing of listed companies and does not exist in the debt financing of listed companies [15].

Capital structure is the result of corporate financing, also affected by the mispricing of securities. Based on a study, there is a long-term negative relationship between market timing and the firm's capital structure [16]. However, other researchers point that the market timing has a very short impact on the capital structure of listed companies [17-19].

Considering financial-constraints, a group of scholars point out that the overestimation of stock prices has a positive effect on the financing of financial-constraint companies and has no significant effect on nonfinancial-constraint companies [20]. However, other scholar analyzes the stock repurchase of Canadian companies from 1998 to 2007 and find that equity financing behavior is consistent with the market timing theory only when there is no external financial-constraint [21]. The stock market bubble of the 1990s, pointing out that the mispricing has a positive impact on equity financing of companies with financial constraints, but have no significant effect on their debt financing. However, for non-financialconstraints companies, there is no significant effect on their equity and debt financing. Research shows that overvaluation of shares will promote equity financing of enterprises with different financing constraints. however, market mispricing only significantly affects the debt financing of companies with high financing constraints. The second part is the 
theoretical analysis and hypothesis; the third part is the empirical analysis; the fourth part is the conclusion.

\section{THEORETICAL ANALYSIS AND HYPOTHESIS}

\subsection{Capital Market Mispricing and Corporate Equity Financing}

Fluctuations in share prices create opportunities for companies to utilize the overvaluation of shares to refinance or the undervaluation of shares to repurchase equity. With the ineffectiveness of China's capital market and the high concentration of equity and equity-financing preference of listed companies, controlling shareholders of listed companies often manipulate managers' decisions to utilize the favorable market timing for equity financing to maximize their own interests.

Hypothesis 3.1: The mispricing of capital markets has a positive effect on corporate equity financing.

\subsection{Capital Market Mispricing and Corporate Debt Financing}

First, due to the "Herding Effect", the high investment sentiment of the stock market investors will drive the investment in the bond market. Second, investors will update the allocation of their existing assets and increase the investment proportion of bonds or other financial products to avoid the risk of the stock market or carry out arbitrage activities when the volatility of the stock price exceeds the expectation of investors, also called "Spillover Effect". As a result, bond demand increases, and corporate debt financing costs decrease. However, due to the lagging development of China's bond market and deficiencies in the corporate bond market, corporate bond return and security cannot meet the needs of investors. The effect of mispricing on the debt financing of China's listed companies may be weakened.

Hypothesis 3.2: The mispricing of capital markets has a positive effect on corporate debt financing.

\subsection{Capital Market Mispricing and Equity Financing of Enterprises} with Different Financial-Constraints

Corporate financial-constraints have increased the cost of capital, restricted financing scale and prevented external financing of enterprises. So high financial-constraints enterprises are more inclined to utilize the mispricing to obtain low-cost equity financing. However, considering the restriction of equity financing in China capital market, the equity financing of listed companies with high financial-constraints is difficult to carry out. So, the effect of mispricing on the equity financing of companies with different financial-constraints is unclear.

Hypothesis 3.3a: The mispricing of capital markets has a higher positive effect on equity financing of companies with high financial-constraints than companies with low financing constraints.

Hypothesis 3.3b: The mispricing of capital markets has a higher positive effect on equity financing of companies with low financial-constraints than companies with high financing constraints.

\subsection{Capital Market Mispricing and Debt Financing of Enterprises with Different Financial- Constraints}

The existence of equity financing restrictions makes it impossible for enterprises to fully utilize market timing. Considering that overestimation of the stock price will reduce of the debt cost, the enterprise with high financial-constraints will increase its debt financing in order to avoid equity financing restrictions. However, for enterprises with low financial constraints, the debt financing is less affected.

Hypothesis 3.4: The mispricing of capital markets has a higher positive effect on debt financing of firms with high financial-constraints than firms with low financial-constraints.

\section{EMPIRICAL RESEARCH}

\subsection{Sample Composition and Variable Definition}

We use the annual data of A-share listed companies from 2006 to 2015, excluding financial and insurance companies. The continuous variable data is winsorized at the level of $1 \%$ to avoid the influence of extreme values. All data come from the CSMAR database.

\section{(1) Capital Market Mispricing}

We use discretionary accruals (DACCR) as a measure of mispricing. When the enterprise is overvalued, the value of DACCR will be higher; when the enterprise is undervalued, the value of DACCR will be lower. DACCR is calculated as follows:

First, calculate accruals (ACCR): ACCR=Net profit - Net cash flow from operating activities of the company.

Second, regression of the accrued profits of Company $j$ of the year $t$ is as follows:

$$
\frac{A C C R_{j, t}}{A_{j, t-1}}=\beta_{0} \frac{1}{A_{j, t-1}}+\beta_{1} \frac{\Delta S A L E S_{j, t}}{A_{j, t-1}}+\beta_{2} \frac{P P E_{j, t}}{A_{j, t-1}}+\varepsilon_{j, t}(1)
$$

Where, $A_{j, t}$ is the total assets of enterprise $j$ in year $t, \Delta$ SALES $_{j, t}$ is the increase of sales revenue of enterprise $\mathrm{j}$ in year $\mathrm{t}, \mathrm{PPE}_{\mathrm{j}, \mathrm{t}}$ is the net value of fixed assets of enterprise $j$ at the end of year $t$.

Third, using regression coefficients $\beta_{0}, \beta_{1}, \beta_{2}$, calculate NDACCR and DACCR by sector for each year:

$$
\begin{aligned}
& N D A C C R_{i, t}=\beta 0^{\wedge} \frac{1}{A_{i, t-1}}+\beta 1^{\wedge} \frac{\Delta S A L E S_{i, t}-\Delta A R_{i, t}}{A_{i, t-1}}+\beta_{2} \wedge \frac{P P E_{i, t}}{A_{i, t-1}}(2) \\
& D A C C R_{i, t}=\frac{A C C R_{i, t}}{A_{i, t-1}}-N D A C C R_{i, t}(3)
\end{aligned}
$$

(2) Financial-constraints

Early researches use dividend payout as a measure of financialconstraints. High financial-constraints choose to pay a low dividend in order to obtain the maximum amount of low-cost internal funds, while low financial-constraints will pay a high dividend. Many scholars have used the dividend payout scale to measure corporate financial constraints. We use the dividend payout as the proxy index of financial constraints. The enterprises with dividend $<0.05$ yuan are classified as high financialconstraints, and the enterprises with dividend $\geqq 0.05$ yuan are classified as low financial-constraints.

(3) Other Variable Definitions

Table 1: Variable Definitions

\begin{tabular}{cl}
\hline Variable symbol (name) & Calculation method \\
\hline Equity-increase & $\begin{array}{l}\text { (Current total owners' equity - Current surplus reserve - Current undistributed profits) - } \\
\text { (Equity growth rate) }\end{array}$ \\
& (Total owners' equity at the previous period - Surplus reserves at the previous period - \\
& Undistributed profits at the previous period) $\} /$ Total assets at the end of the period; \\
Representing external equity financing
\end{tabular}

Debt-increase

(Total debt growth rate)

DACCR (Stock wrong pricing)

Q (Tobin's Q)

Lev (Asset-liability ratio)

CF (cash flow)
[(Current total liabilities - Total liabilities at the previous period) /Total assets at the previous period], representing total debt financing

Discretionary accruals, see above

(Equity market capitalization-Net debt market capitalization) / Total assets

Total liabilities / Total assets

Net operating cash flow / Total assets at the beginning of the period 
Cash (Monetary funds)

Size (Company Size)

Industry (Industry dummy variables)

Year (Year dummy variable)
The monetary funds held at end of the period / The total assets at beginning of the period

The Natural logarithm of the current total assets (billion)

Control the industry effect

Control the year effect

\subsection{Model Design}

We use panel regression, taking DACCR as explanatory variable, taking Tobin's Q, enterprise cash flow, debt-to-asset ratio, firm size and monetary capital as control variables, to explore the effect of the mispricing on the choice of financing for enterprises with different financial-constraints.

Aiming at the effect of mispricing on corporate equity and debt financing, a linear regression model is established as follows:

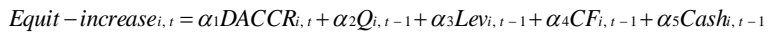

$+\alpha_{6}$ Size $_{i, t-1}+\sum_{j}$ Industry $_{j}+\sum_{i}$ Year $_{i}+\varepsilon_{i, t}$
Debt-increase $i_{, t}=\alpha_{1} D A C C R_{i, t}+\alpha_{2} Q_{i, t-1}+\alpha_{3}$ Levi,t $-1_{i}+\alpha_{4} C F_{i, t-1}+\alpha_{5}$ Cash $_{i, t-1}$ $+\alpha_{6}$ Size $_{i, t-1}+\sum_{j}$ Industry $_{j}+\sum_{i}$ Year $_{i}+\varepsilon_{i, t}$

Considering different levels of financial-constraints, the research objects are divided into two categories according to the level of dividend payment-_high financial-constraints and low financial-constraints. Then regression is carried out using model (4)and (5).

\subsection{Regression Results}

(1) The Regression of the Equity and Debt Financing on the Mispricing Respectively

Table 2: The Regression Results of the Equity and Debt Financing on the Mispricing Respectively

\begin{tabular}{|c|c|c|c|c|c|c|}
\hline Variable & $\begin{array}{l}1 \\
\text { Equity-incre }\end{array}$ & $\begin{array}{l}2 \\
\text { Equity-incre }\end{array}$ & $\begin{array}{l}3 \\
\text { Equity-incre }\end{array}$ & $\begin{array}{l}4 \\
\text { Debt-incre }\end{array}$ & $\begin{array}{l}5 \\
\text { Debt-incre }\end{array}$ & $\begin{array}{l}6 \\
\text { Debt-incree }\end{array}$ \\
\hline DACCRi,t & $0.0778^{* * *}(4.249)$ & $0.0836^{* * *}(4.170)$ & $0.0964^{* * *}(5.060)$ & $0.0837^{* * *}(4.247)$ & $0.0796^{* * *}(4.037)$ & $0.0631^{* * *}(6.161)$ \\
\hline Qi,t-1 & & $0.0142^{* * *}(8.635)$ & $0.0138^{* * *}(7.134)$ & & $-0.0104^{* * *}(-5.496)$ & $0.0044^{* * *}(4.193)$ \\
\hline Levi,t-1 & & $0.0282^{* * *}(3.449)$ & $0.0194^{* *}(2.091)$ & & $-0.0228^{* * *}(-2.181)$ & $0.0011(0.180)$ \\
\hline CFi,t-1 & & & $\begin{array}{l}0.0482^{* *} \\
(1.991)\end{array}$ & & & $0.0025(0.166)$ \\
\hline Cashi,t-1 & & & $-0.0524^{* * *}(-3.442)$ & & & $-0.0295^{* * *}(-3.411)$ \\
\hline Sizei,t-1 & & & $-0.0046^{* *}(-2.455)$ & & & $0.0113^{* * *}(9.967)$ \\
\hline Constant & $0.0633^{* * *}(37.064)$ & $0.0267^{* * *}(4.820)$ & $0.0464^{* * *}(4.774)$ & $0.0998^{* * *}(40.308)$ & $0.1327^{* * *}(18.706)$ & $0.0117^{* *}(2.101)$ \\
\hline
\end{tabular}

Notes. ${ }^{*} \mathrm{P}<0.10,{ }^{* *} \mathrm{P}<0.05,{ }^{* * *} \mathrm{P}<0.01$, where $\mathrm{P}$ is the marginal probability level;t-statistics in parentheses; $t-1$ indicates lagging for one year. The below table is same.

From table 2, the first three columns show that the regression coefficient of DACCR is significantly positive, regardless of the control variables. Mispricing has a significant positive impact on the equity financing of enterprises. The last three columns show that mispricing also has a significantly positive effect on the debt financing of enterprises. Hypothesis 3.1 and Hypothesis 3.2 are established.

(2) The Regression of Equity Financing with Different Financialconstraints Enterprises on Mispricing

Table 3: The Regression Results of Equity Financing with Different Financial-constraints Enterprises on Mispricing

\begin{tabular}{|c|c|c|c|c|c|c|}
\hline \multirow{3}{*}{$\begin{array}{l}\text { Variable } \\
\text { DACCR }_{\mathrm{i}, \mathrm{t}}\end{array}$} & \multicolumn{6}{|c|}{ Financial-constraints Level } \\
\hline & \multicolumn{2}{|c|}{$\begin{array}{l}\text { Low level of financial-constraints } \\
\text { (Dividend payout } \geq 0.05 \text { ) }\end{array}$} & \multicolumn{4}{|c|}{$\begin{array}{l}\text { High level of financial- constraints } \\
\quad \text { (Dividend payout }<0.05 \text { ) }\end{array}$} \\
\hline & $0.0780 * * *(3.463)$ & $0.0933^{* * *}(4.1497)$ & $0.1278^{* * *}(5.347)$ & $0.0610^{* * *}(3.140)$ & $0.0727 \quad * * *$ & $0.0729^{* * *}(3.322)$ \\
\hline $\mathrm{Q}_{\mathrm{i}, \mathrm{t}-1}$ & & $-0.0220^{* * *}(-6.449)$ & $-0.0146^{* * *}$ & & $-0.0377^{* * *}(-8.815)$ & $-0.0053^{* *}(-2.021)$ \\
\hline $\operatorname{Lev}_{\mathrm{i}, \mathrm{t}-1}$ & & $0.0698^{* * *}(3.785)$ & $0.0668^{* * *}(3.405)$ & & $0.0271 *(1.734)$ & $0.0184 *(1.598)$ \\
\hline $\mathrm{CF}_{\mathrm{i}, \mathrm{t}-1}$ & & & $0.0345(1.034)$ & & & $0.0696^{* *}(1.989)$ \\
\hline $\operatorname{Cash}_{\mathrm{i}, \mathrm{t}-1}$ & & & $-0.1290^{* * *}(-5.629)$ & & & $-0.0217(-0.951)$ \\
\hline Size $_{i, t-1}$ & & & $0.0192^{* * *}(6.169)$ & & & $0.0134^{* * *}(5.194)$ \\
\hline Constant & $0.0685^{* * *}(6.792)$ & $\begin{array}{l}0.0867^{* * *} \\
(8.241)\end{array}$ & $0.0720^{* * *}(5.986)$ & & & $0.0383^{* * *}(2.951)$ \\
\hline R-squared & 0.1161 & 0.1257 & 0.1480 & 0.1049 & 0.1331 & 0.1606 \\
\hline
\end{tabular}


The data in Table III show that the regression coefficients of the mispricing are all significantly positive, further verifying hypothesis 3.1. The positive influence of mispricing on the high financial-constraints enterprises is lower than that of low financial-constraints enterprises. Hypothesis $3.3 \mathrm{~b}$ is established.

(3) The Regression of the Debt Financing with Different Financialconstraints Enterprises on mispricing

Table 4: The Regression Results of Debt Financing with Different Financing Constraints Enterprises on the Mispricing

\begin{tabular}{|c|c|c|c|c|c|c|}
\hline \multirow{3}{*}{\begin{tabular}{|l} 
Variable \\
DACCR $_{\mathrm{i}, \mathrm{t}}$ \\
\end{tabular}} & \multicolumn{6}{|c|}{ Financing Constraints Level } \\
\hline & \multicolumn{3}{|c|}{ Low level of financing constraints (Dividend payout ratio $\geq 0.05$ ) } & \multicolumn{3}{|c|}{ High level of financing constraints（Dividend payout ratio<0.05) } \\
\hline & $0.0894^{* * *}(2.790)$ & $0.0632^{* * *}(3.176)$ & $0.0926^{* * *}(4.975)$ & $0.0912^{* * *}(5.924)$ & $0.1096^{* * *}(3.852)$ & $0.1128 * * *(3.962)$ \\
\hline$Q_{i, t-1}$ & & $0.0165^{* * *}(5.745)$ & $0.0149^{* * *}(4.635)$ & & $-0.0290^{* * *}(-5.515)$ & $-0.0240^{* * *}(-4.3903)$ \\
\hline Levi,t-1 & & $0.0415^{* *}(2.5130)$ & $0.0316 *(1.746)$ & & $-0.1912^{* * *}(-9.877)$ & $-0.1961^{* * *}(-10.093)$ \\
\hline $\mathrm{CF}_{\mathrm{i}, \mathrm{t}-1}$ & & & $-0.1212^{* * *}(-2.964)$ & & & $0.0867 *(1.828)$ \\
\hline Cash $_{\mathrm{i},-1}$ & & & $-0.1269^{* * *}(-5.092)$ & & & $-0.0814^{* *}(-2.480)$ \\
\hline Size $_{\mathrm{i}, \mathrm{t}-1}$ & & & $-0.0036(-1.167)$ & & & $0.0094^{* * *}(2.650)$ \\
\hline Constant & $0.1100^{* * *}(32.522)$ & $0.0366^{* * *}(3.144)$ & $0.0856^{* * *}(5.105)$ & $0.0886^{* * *}(10.374)$ & $0.0508^{* * *}(4.366)$ & $0.0436^{* * *}(2.774)$ \\
\hline R-squared & 0.1054 & 0.1119 & 0.1259 & 0.1090 & 0.1642 & 0.1665 \\
\hline
\end{tabular}

Table 4 shows that the regression coefficients of the mispricing are all significantly positive, further verifying hypothesis 3.2. The positive effect of mispricing on high financial-constraints enterprises debt financing is stronger than that of low financial-constraints enterprises. Hypothesis 3.4 is established.

\section{CONCLUSION}

First, the mispricing has a significant positive impact on the equity and debt financing of enterprises. There is a clear market-timing behavior in the financing decision of listed companies. Second, with the introduction of financial constraints, the empirical results show that the positive impact of the mispricing on the equity financing of firms with high financing constraints is lower than that of the firms with low financing constraints. For the debt financing of enterprises, the regression result is just the opposite. In addition, we argue that Chinese listed companies face many financing constraints from external capital markets to internal financial status of enterprises, and the ability of enterprises to use the mispricing for financing is largely constrained. Therefore, enterprises with high financial constraints will choose to engage in debt financing and pass the positive signals of business operation to the market, resulting in that the mispricing has a stronger positive effect on debt financing of enterprises with higher financial-constraints than those with low financialconstraints.

\section{REFERENCES}

[1] Bie, T.D., Haan, L.D. 2007. Market Timing and Capital Structure: Evidence for Dutch Firms [J]. The Economist, 155 (2), 183-306.

[2] Brau, J.C., Fawcett, S.E. 2006. Initial Public Offerings: An Analysis of Theory and Practice [J]. Journal of Finance, (1), 399-436.

[3] Bakke, T.E., Whited, T.M. 2010. Which Firms Follow the Market? An Analysis of Corporate Investment Decisions [J]. The Review of Financial Studies, 23 (5), 1941-1980.

[4] Campello, M., Graham, J.R. 2013. Do Stock Prices Influence Corporate Decisions? Evidence from the Technology Bubble [J]. Journal of Financial Economics, (1),: 89-110.

[5] Dong, M., Loncarski, I., Horst, J.T., Veld, C. 2012. What Drives Security Issuance Decisions: Timing, Pecking Order, or Both? [J]. Financial Management, 41 (3): 637-663.

[6] Graham, J.R., Harvey, C.R. 2001. The theory and Practice of Corporate Finance: Evidence from the Field [J]. Journal of Financial Economics, (3),187-243.

[7] Guo, J., Zhang, Y.B. 2012. Business timing or government timing? The Influence of Timing Choice of IPO Market on Capital Structure under the Background of Specific System in China [J]. Journal of Financial
Research, (7): 137-153.

[8] Hovakimian, A., Opler, T., Titman, S. 2001. The debt-equity choice [J]. Journal of Financial and Quantitative Analysis, (36),1-24.

[9] Leary, M.T., Roberts, M.R. 2005. Do firms re-balance their capital structures? [J]. Journal of Finance, 60 (6), 2575-2619.

[10] Luo, Q., He, J. 2015. Mispricing of Stock Market and Decision of Investment and Financing by Controlling Shareholders [J]. Economic Management, (1),: 109-118.

[11] Li, J.P., Xu, L.B. 2015. Mispricing, Financial Constraints and Corporate Financing Choice [J]. Journal of Financial Research, (12): 114129.

[12] Lu, T.P., Zhang, D.X. 2014. Financing Needs, Financing Constraints and Earning Management [J]. Accounting Research, (1), 35-41.

[13] Ma, W.C. 2012. Monetary Policy, Market Timing and Equity Financing [J]. Nanjing Business Review, (2), 46-65.

[14] Maureen, F., McNichols, Stephen R, S. 2008. Does Earnings Management Affect Firms Investment Decisions? [J]. The Accounting Review, 83 (6), 1571-1603.

[15] Maker, J.F., Kasturi, P.R. 2006. Partial adjust toward target capital structures [J]. Journal of Financial Economics, 79 (3), 469-506.

[16] Baker, M., Wurgler, J. 2002. Market timing and capital structure [J]. The Journal of Finance, 57 (1),1-32.

[17] Rangan, S. 1998. Earnings Management and the Performance of Seasoned Equity Offerings [J]. Journal of Financial Economies, (1), 101122.

[18] Spiess, D.K., Affleck-Graves, J. 1999. The long-run performance of stock returns following debt offerings [J]. Journal of Financial Economics, 54 (1), 45-73.

[19] Welch, I. 2004. Capital structure and stock returns [J]. Journal of Political Economy, (1), 106-131.

[20] Wang, Z.W., Zhu, W.X.,Zhao, D.Q. 2007. Market Timing in Seasoned Equity Offerings with Security Issue Regulation and Its Impact on Capital Structure [J]. Nankai Business Review, (6), 40-46.

[21] Xu, H.P., Yang, G.C. 2013. The Cross-market Impacts of Investor Sentiment in Stock Makets: On the Effect of Investor Sentiment on Bond Issue Costs [J]. Journal of Finance and Economics, (2), 47-57. 